\title{
ЗАРУБЕसНЫЙ ОПЫТ
}

\section{E. Rudawska}

U.D.C. 336

\section{SOCIAL CONSCIENCE OF FINANCIAL INSTITUTIONS AS A SOLUTION FOR RETAINING RELATIONSHIPS WITH CUSTOMERS IN THE FACE OF THE GLOBAL CRISIS}

\begin{abstract}
Poland's economic environment has undergone dramatic changes in the last two years. Consequently, companies have become more insecure and experienced an increase in risk to their activities; moreover, consumers have become worried. Poland's sector of banking services has suffered greatly due to the crisis, especially as far as their image is concerned. The research shows that a $20 \%$ decline in the sense of security, credibility and trust has been observed compared to the time span from two years ago. The crisis has caused banks to reconsider their previous business models. As institutions of public trust they have to become more engaged on social issues. This study presents examples of social commitment of Poland's financial institutions during the crisis and shows the influence of these activities on customers'loyalty in the face of the crisis. Social activities performed by banks between 2008 and 2010 in Poland have also been assessed.
\end{abstract}

Keywords: social responsibility, banks, crisis in Poland, customer relations

\section{A scale of global crisis in Poland}

Poland's economic environment has undergone dramatic changes in the last two years. Consequently, companies have become more insecure and experienced an increase in risk to their activities; moreover, consumers have become worried. Companies worried by alarming reports about the economic crisis have been forced to cut or even withdraw their investments. As a result, the unemployment rate has risen and people's income has declined. Therefore, the consumption volume has decreased, and the perception and structure of price have changed. Consumers have become more cautious; they have made more sensible and well-thought-out decisions and they have been less willing to spend money. The fact that the crisis has been much-publicized by the national mass media resulted in a fall in consumers' trust in companies and an increase in their uncertainty. $43 \%$ of the Poles have admitted that the media's focus on the crisis has deteriorated the current situation in Poland, and the crisis has been exaggerated ${ }^{1}$. The fact that the crisis has been

\footnotetext{
${ }^{1}$ The research was conducted by Research International, between October and December 2009 on the sample of 10804
}

widely covered by the media has badly affected its perception and increased Poles' fears. The research showed that out of ten countries that participated in the research, Poland was the most tired with the subject of the crisis covered by the media. It was difficult for the Poles to predict their financial situation exactly (chart 1). One fourth of the respondents expected their situation to improve by the end of 2009 , while one fifth of them expected their situation to deteriorate. $22 \%$ of the respondents did not expect their financial situation to change.

The financial crisis has increased Poles' expenses on foodstuffs, constant payments, medicines and other necessities. Surprisingly, only $7 \%$ of the adult Poles, who have been influenced by the crisis, indicated that it affected their work and professional life. The majority of the respondents indicated that the situation in companies or businesses they work in deteriorated; they also complained about the unemployment, pay cuts and delays in salary pay-

respondents, including 1320 from Poland. Apart from Poland, the following countries participated in the research: Austria, Belgium, Czech Republic, Hungary, Ireland, Holland, Romania, Slovakia and Switzerland. 


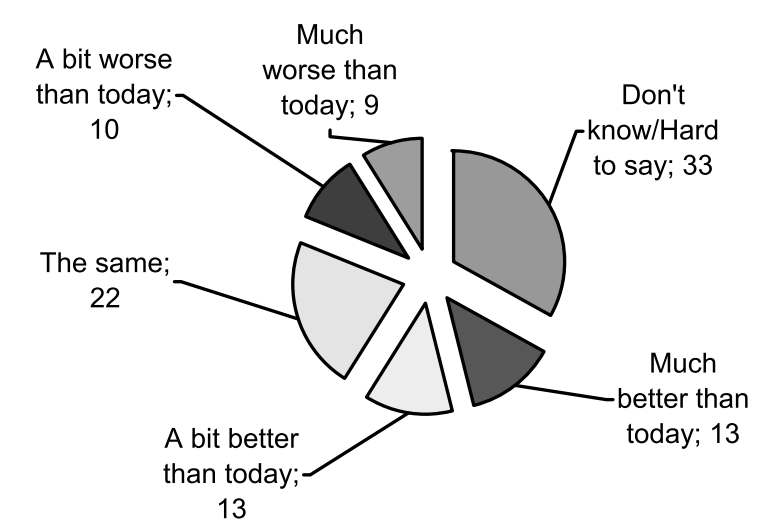

Chart 1. Expected financial situation by the end of 2009 (in \%) (Source: Research conducted by S. A. Gemius on the subject of "Finances and financial plans of Internet users», March-April 2009)

ments. The facts mentioned above lead to the conclusion that the Poles are rather optimistic about the crisis. It is supported by the research on the influence of an economic setback on Europe's citizens conducted by the Gallus Institute for the European Commission. The citizens of Lithuania, Hungary, Malta and Greece declared themselves to be most affected by the crisis, while the citizens of Poland presented the most optimistic attitude (Czubkowska, 2009).

Companies operating in Poland seem to have been exposed to an adverse influence of the crisis. More than $80 \%$ of Polish companies are affected by the global financial crisis, while $93 \%$ of the respondents are afraid of problems caused by the crisis in 2009 (chart 2) ${ }^{1}$.

As can be seen from the report prepared by the Bureau of Economic Information (InfoMonitor), an index of security in business relations declined from 10.3 points in January 2009 to 3.81 points in March 2009, which made it the lowest level since November 2007. Three quarters of the companies observed that their clients fail to meet payment dates, more than a half of the companies lost their customers and contracts. In Poland almost $60 \%$ of the respondents from the financial sector and $49 \%$ of service providers have faced the hold back of payments and lost liabilities.

\section{Crisis on the market of banking services in Poland}

The image of the banking services sector in Poland has been negatively influenced by the crisis. On the one hand the financial sector has been blamed for the economic crisis, but on the other hand banks

\footnotetext{
${ }^{1}$ Business Centre Club, December 2008.
}

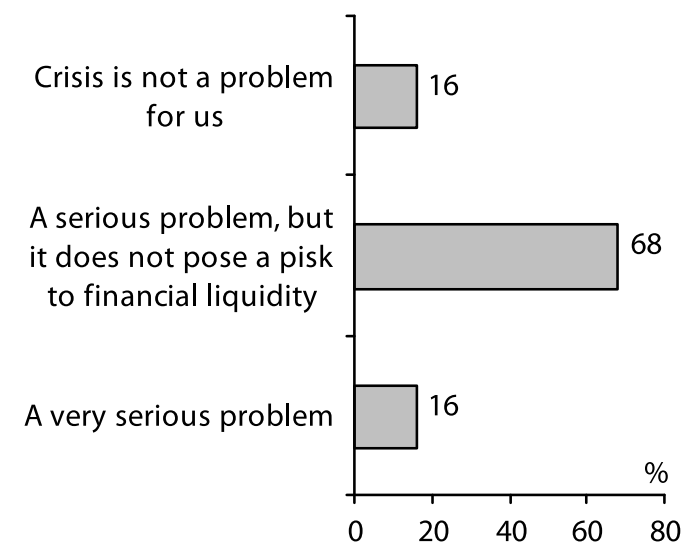

Chart 2. The significance of the global financial crisis for Polish companies (Source: Research conducted by BCC, www.ceo.cxo.pl, dated 5th January 2009)

have changed their attitude towards their customers thus spoiling their image.

The research conducted by Pentor, which specializes in research on a financial services market in Poland, indicates that a general view of Poland's banking sector has deteriorated in the last months ${ }^{2}$. Almost a $20 \%$ decline in positive opinions has been observed. Whereas in 2007 almost half of the Poles assessed banking service providers very high or high, in 2009 the proportion dropped to $30 \%$. It should also be underlined that between October 2008 and February 2009 the proportion of respondents who expressed lower opinions of Poland's banking sector doubled.

The latest research on a banking services market in Poland has demonstrated an alarming fall in trust and credibility of financial services providers (chart 4). The research clearly shows that levels of security, credibility and trust have declined by $20 \%$ on average, compared to the time span from two years ago. Bad condition of Poland's market of banking services is also reflected by the proportion of respondents demonstrating an increased trust in banks, which fell from 35\% to 5\% between August 2008 and April 2009. A decrease in trust is declared in most cases by customers of foreign banks and banks with dominating foreign capital, in least cases by customers of cooperative banks.

On the basis of this research it is possible to conclude the banks in Poland are currently struggling with the crisis of public trust. Such a situation needs to be perceived as particularly dangerous due to the fact that banks function as institutions of public trust. Banks must ensure security of the entrusted

\footnotetext{
2 Changes in perception and image of Poland's banking sector'2009, a report from research conducted by Pentor agency, Warszawa, April 2009.
} 


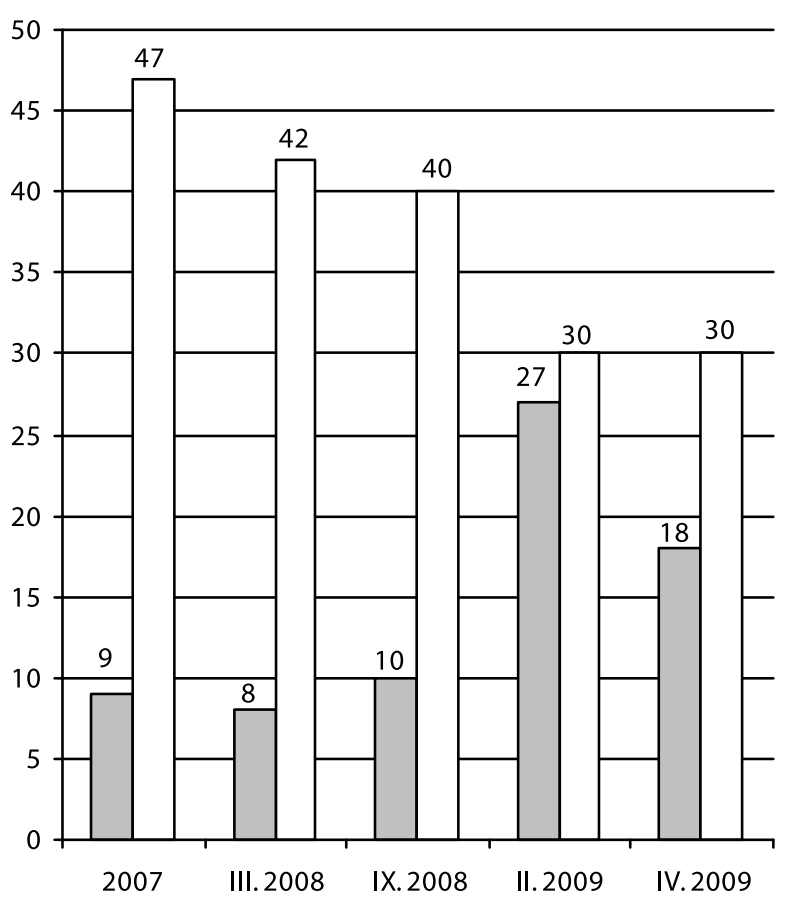

$\square$ Verybad + rather bad $\square$ Very good + rather good

Chart 3. Opinions of Poland's banking sector (Source: Changes in perception and image of Poland's banking sector'2009, a report from research conducted by Pentor agency, Warszawa, April 2009, p. 4)

resources as well as stability and continuity of their functioning by creating credible, safe and trustworthy image. Banking activities are based on trust, which leads customers to entrust their financial means to a bank. Both the potential and the power of bank-customer relations are mainly caused by mutual trust. It should also be underlined that earning public trust is a long-term activity, but it might be lost as a result of one false move. Loss of trust may result in loss of existing and potential customers. Trust is developed through everyday contacts with customers.

The significance of credibility and a sense of security of a banking sector also relates to two roles attributed to banks, i. e. being a factor stabilizing the economy and determining economic development. No bank can operate alone, regardless of the system, because banks need to participate in a system of mutual payments. Therefore, a bank failure causes a series of negative consequences for the whole economy, including a disturbance of its stability. The crisis on global financial markets has triggered off numerous discussions about a range of crisis in Poland. On the one hand media informed that the banking sector in Poland generated very high profit in 2008, but on the other hand banks addressed to the Polish government and called for activities prevent-
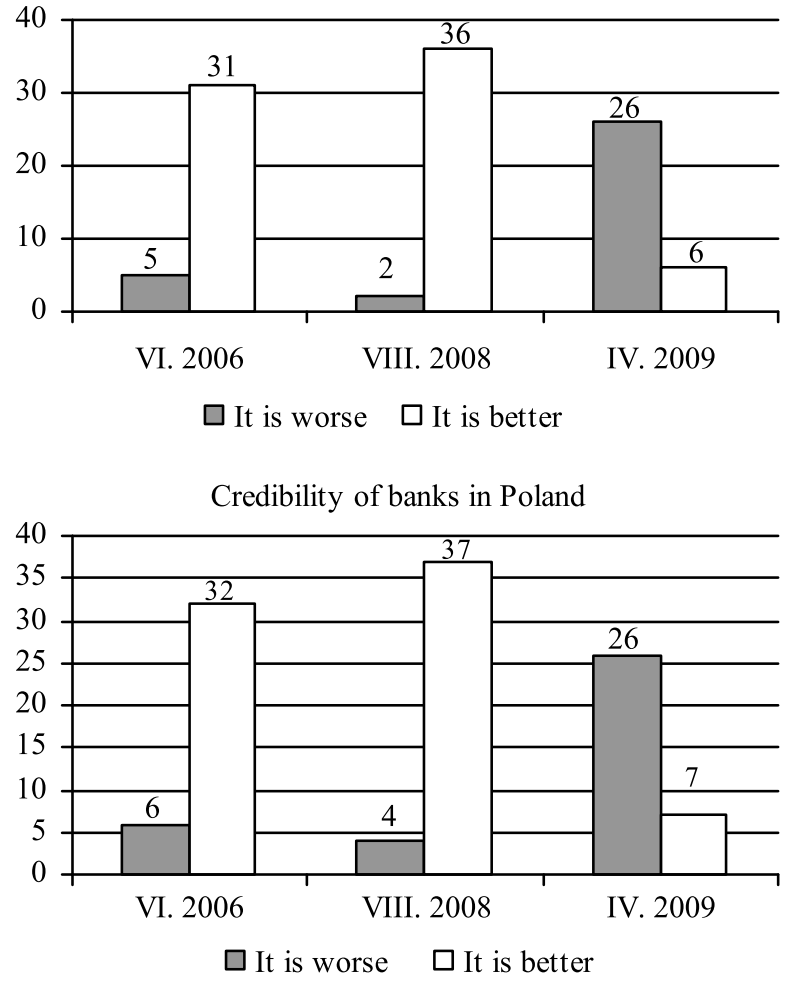

Trust in banks in Poland

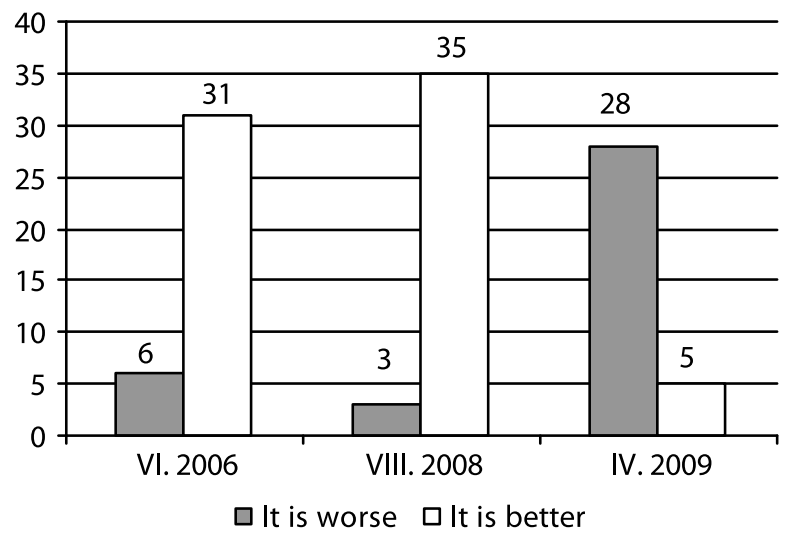

Chart 4. Levels of security, credibility and confidence in Poland's banking sector compared to the time span from two years ago

(Source: Changes in perception and image of Poland's banking sector'2009, a report from research conducted by Pentor agency, Warszawa, April 2009, p. 5)

ing a potential crisis on a banking market. This can be illustrated be an increase in deposit guaranties in order to secure banks against the outflow of money from deposits (at present the Banking Contingency Fund (Bankowy Fundusz Gwarancyjny) ensures a $100 \%$ return of financial means up to 50,000 euro), or when necessary rendering assistance to financial institutions by the State Treasury in order to maintain financial liquidity. Banking experts and entrepreneurs praised the government for such moves but the average Poles had doubts about the pledged sup- 


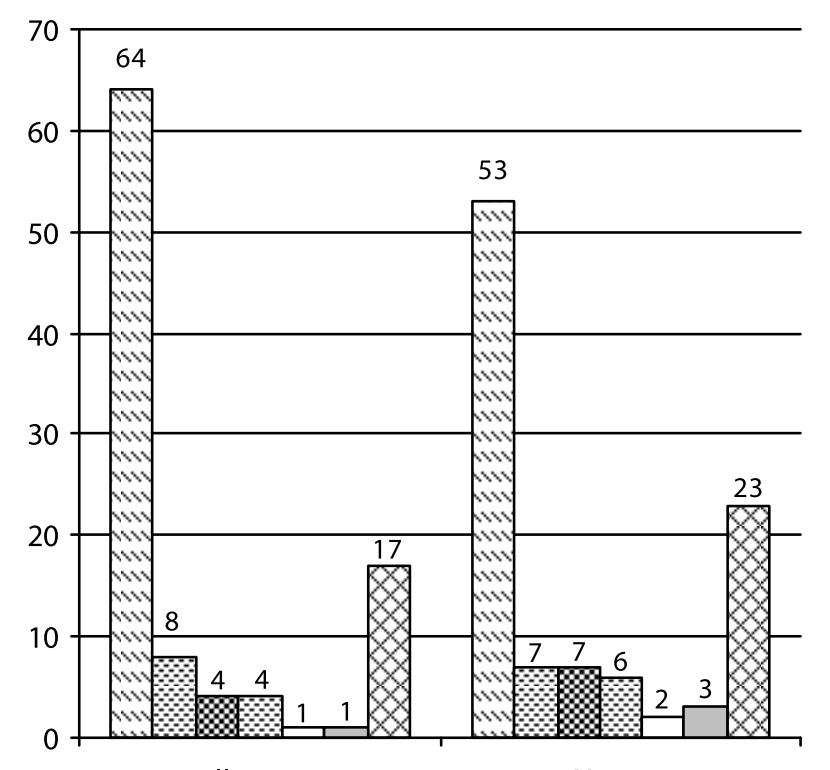

II. 2009

$\checkmark$ Nothing, I will wait for the crisis to end

回 I will wait for other people to act

I will withdraw some money from the bank

ㅇ I will withdraw all money

$\square$ I will deposit my savings at several banks

$\square$ I do not have savings

囚I do not know / Refusal to answer

Chart 5. What do you intend to do with your money deposited at the bank to protect yourself against effects of the crisis? (Source: Changes in perception and image of Poland's banking sector'2009, a report from research conducted by Pentor agency, Warszawa, April 2009, p. 5)

port. Their opinions expressed on web portals suggested that taxpayers were unable to puzzle out why banks, which generated record profits, demanded support from public institutions, thus striving for taxpayers' money. It seems that any public support requires banks to prove that they act in the interests of institutions not of their own. However according to internet users banks have not taken any actions of their own accord that would be aimed at improving their situation on the market. Internet users cited the examples of world banks which pay for guaranties issued, e.g. shareholders commit themselves to transfer future profits to increase the capital, boards of directors resign from parts of their salaries. One of the internet users expressed his opinion in the following way: «...financial crisis has become a source of profits for banks in Poland. Almost all banks have decided to raise mortgage interest rates. ... Financial crisis has been a good excuse for raising the most important parameter of credit interest rates - credit margin...».

The article does not make any attempt to judge the opinions expressed by the Poles, but basing on them one can conclude that the Poles are fairly critical of actions taken by banks in the face of the economic crisis, especially of their claims against the state.

Despite the unfavourable judgment of the situation on a banking services market, Polish banks' customers are quite prudent. $60 \%$ of them have no intention to change the way their money is managed in order to protect themselves against effects of the crisis. The Poles declare that they intend to wait for the end of the crisis (chart 5).

Bearing in mind the fact that banks stabilize the economy, as well as the fact that the crisis and its range are beyond banks' capabilities, which are unable to counteract its effects, one should not be surprised that banks expect support from the state. Nevertheless, one can suppose that the Polish society would be more favourably inclined towards banks' attempts at receiving financial support if banks were more engaged in large-scale socially responsible activities. Since the government supports the financial sector with taxpayers' money, banks' boards of directors have to be responsible both to shareholders and the society.

\section{Social responsibility of banks and the economic crisis}

In such a market situation financial institutions in Poland have been forced to intensify their struggle for customers and fight for developing and maintaining long-term, profitable customer relations in the face of the crisis. The crisis has made companies, including banks, reconsider their previous business models. As institutions of public trust banks are faced with greater challenges than other entities operating in the market economy. Banks are expected to undertake long-term, large-scale activities resulting from widely understood public commitment. Banks should consider both shortterm objectives, related to their sustaining on the market during crisis, and the results of long-term activities. Crisis is a test of business strategies. If the objectives are achieved in difficult conditions, it means that the strategies have been well-designed. Unfortunately, many tools applied to build these relations are easily copied and commonly used, which render them increasingly less effective. Additionally, they are a short-term solution, which facilitates to increase sales only temporarily. It mainly refers to product or price offers made by 
financial institutions. Therefore, companies resort to other ideas which may determine their success on the market. An increasing number of companies in Poland, including banks, adopt solutions which are more difficult to copy because they refer to an organizational culture of a company, e. g. a social responsibility strategy.

According to this concept, contemporary companies should serve the public and accomplish both economic and social objectives, namely all decisions taken in a company should aim at profits and advantages for its owners and they should consider long-term interests of other subjects, i.e. stakeholders. This approach has been named CSR (Corporate Social Responsibility). According to this concept, companies should both gain profits and consider the public interest. Companies should focus on fulfilling customers' needs in accordance with the law and the principles of business ethics, as well as acting so that environmental protection is ensured. Companies should also support ecological organizations and campaigns, charities, organize charity events and maintain good relations with a local community. This results in developing and performing actions which are economically valuable, environment-friendly and socially responsible.

If a company does not limit its objectives to strictly financial ones, but focuses also on social objectives, it can increase value for itself and its shareholders. This aim is often advocated as far as contemporary companies are concerned. It is reflected, among other things, by globally available offers of investment funds. Since investors are not only shareholders expecting profit, but also stakeholders, SRI - socially responsible investing has aroused interest. SRI funds invest in socially responsible companies. Investors take advantage of such offers $^{1}$ because of two reasons (Anam, 2008). Firstly, investors avoid companies or businesses whose activities are morally doubtful. Secondly, investing in SRI funds enables them to get high rates of return.

Social objectives fulfilled by banks, and their active involvement in activities advantageous to environment bring intangible benefits. Companies undertake socially minded activities in order to improve their image, or build up customers and business partners' confidence, which let minimize the risk of cooperation, leading in turn to an improvement of a company's competitive position and fulfilment of long-term objectives. Banks which imple-

\footnotetext{
${ }^{1}$ Napływ środków do funduszy ekologicznych wzrósł z 0,6\% w 2005 do $15 \%$ w 2007.
}

ment the concept of social responsibility are more likely to count on an increased interest and loyalty from their customers. However, it should be underlined that such benefits can be expected in the long term. Company image and the way it is perceived by environment is a consequence of consistent, long-term activities. Therefore, social responsibility cannot not be imposed on companies, since it must be understood and accepted by them, and carried out according to society's expectations.

\section{Attitude of the Polish society towards CSR}

An observed fall in confidence in financial institutions, including banks, necessitates search for possibilities of its restoration through socially responsible activities. The author analysed various research conducted throughout the world and in Poland. On the basis of this analysis it is possible to acknowledge previous theoretical deliberations, and supplement them with new observations about significance and the degree of society's acceptance of socially responsible activities. The author intended to present these results in order to substantiate the necessity of developing such activities by banks to accomplish objectives relating to building public trust, and stabilizing their market position in times of the uncertainty and crisis.

The results of international research conducted between August and October 2008 by the Edelman agency, provide very interesting information about respondents' attitudes towards socially responsible activities during a crisis. The research indicates that in the face of a crisis consumers highly value these companies which are committed to socially minded objectives. According to $80 \%$ of the respondents companies should undertake socially responsible activities during a crisis. On the basis of this research it is possible to conclude that companies whose activities are socially responsible can build customers' loyalty even during a crisis. This thesis is proven by the following observations:

1. $70 \%$ of the respondents would definitely continue to be customers of a company during a crisis if it undertook socially responsible activities;

2. $50 \%$ are inclined to recommend a company to their acquaintances if it does such activities;

3. $55 \%$ of consumers indicate that in spite of a crisis they will continue purchasing in a given socially active company, even if it increases prices;

4. Almost $70 \%$ would be ready to pay a higher price for an offer from a socially committed company; 
5. More than a half would support a promotion of products offered by such companies during a crisis.

Customers expect companies to modify ways of financial resources allocation in marketing budgets. According to $63 \%$ of the respondents companies' spending on advertising is too high, and it should be allocated to socially minded activities. Customers consider that it is important for companies to be engaged in social activities, which are vital for customers. As the most important consumers regarded the environmental protection $(84 \%)$, the promotion of health $(86 \%)$, the countering of poverty $(84 \%)$, and the equal access to education (82\%).

Research conducted on a Polish market ${ }^{1}$ indicate that the Poles are increasingly aware of the necessity of undertaking social activities. The Poles are of the opinion that companies not only should incorporate social responsibilities into their business strategies, but also clearly inform customers about their activities. In the last few years half of the Poles have become interested in companies' policies, and one third of them have been actively searching for information about socially responsible activities. In addition, more than a half of customers decide to purchase a product under the influence of information about producer's corporate responsibility. The Poles experience some discomfort when they purchase from socially irresponsible companies, they even stop purchasing because they feel responsible for punishing unethical companies.

\section{Social commitment of banks operating in Poland}

As has been mentioned above, the spread of an idea of social commitment causes banks operating in Poland to focus on developing and maintaining relationships with customers and other market entities, e.g. ecological organizations, local communities or employees. Environmental aspects, interests of local communities and banks' employees receive much attention, because they give banks a chance of a long-term market success. From the observations of banking services market, analyses of secondary materials, such as annual reports, financial reports and banks' strategies, we can conclude that these institutions undertake heightened activities as

\footnotetext{
1 The research was conducted by IMAS International, (the Institute for market Research and Public Opinion in Wrocław) Instytut Badania Rynku i Opinii Społecznej we Wrocławiu ordered by Euro RSCG Sensors. www.marketing-news.pl dated 20 November $2008 \mathrm{r}$.
}

far environmental, social and economic aspects of a social responsibility concept are concerned.

The commitment to environmental issues was manifested by some banks which signed the UNEP international declaration regarding environmental protection and long-term sustainable development. Thus, they committed themselves to take into consideration problems of environmental protection in their future policies. Following the declaration, banks are obliged to observe standards of environmental protection, as well as to recognize long-term, sustainable development of a bank and its customers, which provides a basis for its existence and acceptance from the public (Korenik, 2002). Bank Ochrony Środowiska S. A. (BOŚ S. A.) is a good case in point, since it incorporates the idea of sustained development into its activities. The key mission of this bank is to act in favour of the protection of natural environment, which is connected with the specificity of its activities and statutory regulations concerning cooperation with ecological organizations. From the above we can conclude that this bank is very active in creating values for local communities. BOŚ cooperates with the National Fund for Environmental Protection and Water Management, regional funds for environmental protection and water management, the M. Rataj Foundation for the Development of Polish Villages 2000, the European Fund for the Development of Polish Villages, and many other aid funds. The president of the bank emphasizes that the bank acts according to the principle of sustained development, thus actively participating in the development of regions, and supporting development projects run by self-governmental bodies and entrepreneurs. The bank supports program called "Nature 2000" and establishes cooperation with ecological and nongovernment organizations. It offers popular services called Ekokonto and Ekoprofit, and it donates a part of profit generated by these services to organizations which protect different bird species, i. e. the Polish Association of Bird Protection and the Green Lungs of Poland Foundation.

Banks want to secure their competitive capabilities in the environment which values and fosters ecological awareness. Thus, they favour an active system of environmental protection management (Korenik, 2002). This system requires activities done within a bank, e. g. energy conservation, reduction in paper consumption, paperless money turnover, as well as an ecological approach towards banking services. The following activities are worth 
mentioning among others: preferential credit interest rates for customers who intend to use solar energy, encouraging credit recipients to use management systems based on environmental protection.

Banks are especially active as far as social commitment is concerned. Most financial institutions incorporate goals involving close relationships with their employees into their mission and strategic objectives. PeKaO S. A., PKO BP S. A., Citi Handlowy S. A., Fortis S. A. and Kredyt Bank S. A. are good examples. They underline their concern for creating an attractive and satisfying work environment, attention to balance between employees' professional and private lives, their aspirations to be perceived as best employers in the banking sector. As a result of undertaking such activities, BOŚ bank was awarded the title of "The Solid Employer", for modern and ethical human resources management.

Social commitment of banks is demonstrated by supporting charities and maintaining good relationships with a local community. Many banks act directly by providing undertakings carried out by a local community with financial support, i. e. they sponsor cultural and artistic events, concerts, etc. Banks frequently establish their own charities. A case in point is the ING Foundation for Children, whose aim is to equal chances by providing chronically ill children with education, educating young people about business, helping young people from poor families gain access to higher education. Also, this foundation comprises a program called "In the company of a Lion", whose aim is to provide aid for children affected with cancer. This program was awarded in the Golden Clip 2005 competition, in the Corporate Social Responsibility category. In regard to social commitment, Fortis Bank is similar. A foundation established by this bank is engaged in activities aiming at counteracting expulsion of children and young people from the society. In 2008 the foundation established cooperation with the Society of Children's Friends. Similar to BRE Bank, Fortis joined Strategic Partners of the Responsible Business Forum.

Socially committed activities are becoming increasingly popular. As part of them banks use affinity cards (Grabarz), i. e. credit cards where a certain amount of money (part of commission charged by a bank) is given to a charity every time the card is used. Affinity cards are issued with the approval of non-commercial organizations, and although the cards have their logos, they are not co-branded cards connected with loyalty programs. Affinity cards are issued for philanthropic purposes. Their holders are not entitled to discounts or other benefits. The only benefit is the satisfaction they derive from donating to charities. Although the donated amounts are quite low, they are paid on a regular basis. Affinity cards are offered by the following banks: PKO BP (the card supports the Program of Building Polish Artificial Heart), BISE, BPH, Bank Zachodni WBK, Polbank EFG (together with the Fund for Fulfilled Dreams) and Bank Millennium with WWF. Benefits for a bank stem from the fact that card holders disseminate information about actions they support as well as bank's offers, thus acting as advocates of their banks. By means of affinity cards banks appeal to their customers' emotions, their readiness to help others and their sensitivity, thus strengthening bankcustomer relationships based on trust.

An economic dimension is a vitally important area of social responsibility of banks. It relates to long-term profitability retention parallel to satisfying customers' needs in accordance with the law, business ethics principles and binding rules of conduct. On the basis of the analysis of materials drawn up by banks it is possible to conclude that these institutions are highly active in the discussed area. Banks declare that their priority is to establish lasting customer relationships in accordance with a code of ethics and binding rules of conduct. These codes are called Rules of good bank customs which are a set of rules of conduct relating to banks' activities. According to these rules, banks, as institutions of public trust, commit themselves to obey rules of professionalism, reliability, objectivity and conscientiousness. Information about services and their conditions, provided by banks should be comprehensive, and include additional benefits, charges and risk of an offer.

However, from observations of banks' activities it is possible to infer that as far as this issue is concerned declarations of financial institutions differ from customers' experience. In many cases a declared attractive deposit does not translate into real benefits for customers. It is easy to manipulate customers because of the specificity of bank offer. The price of an offer is complex. Profit from a deposit depends not only on its nominal interest rate (the most distinctive parameter for customers), but also on the way in which interest is calculated, or when it is paid. This information is often given in small print as „footnotes marked with asterisks” (Kowalczyk, 2004). In many cases communication between a bank and its customers is unreliable, yet 
reliable communication is to be one of the main tools used to create an image of a trustworthy institution. This problem should be especially focused on during a crisis, when ethical conduct may determine lasting customer confidence.

On the basis of the analysis of banks and their conduct during the crisis we can divide banks into four groups (Siwek, Sadowski, 2008). The first group comprises banks which introduced new rates or requirements regarding credit rating and customer's own funds for all customers, i.e. both new and those whose applications were being processed, and even those customers who obtained positive credit decisions. Such conduct of banks caused measurable losses for customers. According to financial analysts, Bank Millenium was one of such banks. In the beginning the bank decided to continue credit conditions on the same basis as before for credit applications which were being processed.

However, following a later decision, new rules applied to all customers, who had not signed credit agreements (although they had obtained credit decisions). The new rules concerned an increase in compulsory customer's own funds to $20 \%$ for mortgage loans in zlotys, and 30\% for mortgage loans in foreign currency, an increase in margins, and shortening of mortgage loan period to 35 years. Nordea Bank acted in a similar way, although previous rules applied also to those customers who obtained credit decisions. The second group comprises banks, which changed the rules for customers whose applications were being processed, but they were on preferential conditions. Polbank belonged to this group. It divided its customers into three groups: customers who had received final decisions, customers who had received initial decisions, and those who had not received any decisions yet.

As far as the first group was concerned, the bank continued previous conditions; towards the second group the bank continued rules of calculating the amount of credit, but changed price conditions; the third group was offered completely new conditions regarding calculation of credit capacity (the amount of credit) and price conditions. This group comprised also mBank and Multi Bank, which introduced a smaller increase for customers whose applications were being processed, and a bigger increase for new customers. Two other groups comprised banks which changed conditions instantly, but only for new customers, and banks which did not change conditions for customers whose applications had already been registered, and gave time to new cus- tomers so that they could apply on previous bases. Among banks which did not change credit conditions for processed applications were ING Bank Śląski, PKO BP and Raiffeisen Bank. Kredyt Bank and GE Money Bank were even more favourable to their customers. Not only did they not change conditions for customers who had applied, but they also granted a transitional period for new customers, who could apply for credits on the same basis as before.

\section{Conclusions}

Being institutions of public trust, banks are especially obliged to act in the area of social responsibility. This term refers not only to activities undertaken for the benefit of a local community, but also to high ethical standards, clarity of reporting results, attention to natural environment, and commitment to staff-related matters. Since the market of banking service in Poland has not matured yet, such activities are essential. Thus, banks aim to create a trustworthy image, because their strategies incorporate activities beneficial to banks and their environment. Trust between a company and its customers or business partners is of key importance to ensure the efficiency of conducted activities in a competitive environment. However, trust can prove to be indispensable in times of crisis and uncertainty.

On the basis of the above examples it is possible to conclude that banks are aware of the necessity of undertaking socially responsible activities. All activities done by banks, as part of the social responsibility concept, certainly strengthen customer relationships, and reduce their willingness to transfer to another bank, which is particularly important in times of the crisis and uncertainty on the market. Nevertheless, it should be pointed out that banks' efforts to support large-scale charity or ecological campaigns may be thwarted as a result of mistakes in everyday contacts with customers, or unethical conduct. The situation is particularly significant in times of crisis.

The effectiveness of socially minded undertakings requires integrated and efficient activities as far as the three areas of the concept are concerned. According to research conducted by the Edelman ${ }^{1}$ company, carried out in 18 countries, including Poland, on the subjects of trust and credibility, stakeholders' trust, including customers, towards companies results from all activities undertaken on a day-to-day basis. For $83 \%$ of the respondents

\footnotetext{
${ }^{1}$ Edelman Trust Barometr 2008, http://www.edelman.com.
} 
the trust is not only influenced by the quality of offer and customer service, but also by company's reputation resulting from its commitment to social activities. In this context, the cohesion of information about social commitment of banks should be recognized.

In the next few years the Poles will impose higher demands on companies, which is a consequence of a consumer culture development. People grow wealthy and buy more goods, but they also have rising expectations of purchased offers and companies. At the same time, modern technologies, e. g. the Internet, offer a contemporary society an easier access to information about banks' activities. In such conditions the transparency of communication with customers and operational activities protects customers against effects of the crisis.

Clarity, regularity and plentiful information about activities undertaken in times of crisis, supported by an image of a socially responsible institution, contribute to the establishment of partnership relations with a bank, based on trust and security.

\section{References}

1. Anam, R., (2008), Fundusze ekologiczne coraz popularniejsze, www.eGospodarka.pl, z dnia 01.09.2008.

2. Czubkowska, S., (2009), „Polacy mają kryzys w nosie”, Dziennik.pl z dnia 5 listopada.

3. Grabarz, A., Serce w portfelu, www.marketing-news.pl

4. Korenik, D. (2002), Konkurencyjność i konkurencja banków polskich od lat dziewięćdziesiątych XX wieku, Wydawnictwo Akademii Ekonomicznej we Wrocławiu, Wrocław.

5. Kowalczyk, A., (2004), „Na granicy przyzwoitości”, Bank, no 3, pp. 34-35.

6. Siwek, K., Sadowski, J., (2008), „Część banków oblała egzamin z fair play”; wypowiedź ekspertów finansowych firmy Expander, www.e-banki.blogspot.com, z dnia 27.11.2008

\section{Information about the author}

Edyta Rudawska (Szczecin) - Professor, PhD, Marketing Department, Faculty of Economics and Management of University of Szczecin (ul. Mickiewicza 64 71-101 Szczecin Poland, e-mail: edyta@rudawska.pl). 